\title{
CHEMICAL CHANGES OCCURRING IN THE BODY AS A RESULT OF CERTAIN DISEASES IN INFANTS AND CHILDREN
}

\section{Acute Hemorrhagic Nephritis. Sub-Acute Nephritis; SEVERE Chronic Nephritis}

\author{
BY ALEXIS F. HARTMANN AND DAN C. DARROW
}

With the Technical Assistance of Marie Morton

(From the Department of Pediatrics, Washington Universily School of Medicine, and the St. Louis Children's Hospital)

(Received for publication April 9, 1928)

It is well known that in normal subjects the osmotic pressure of the blood serum averages about 310 osmolar millimoles, and varies but little. Since more than 90 per cent of the serum osmotic pressure is due to electrolyte, it is apparent that metabolism of the latter must tend to be such as to maintain a fairly fixed concentration in the blood plasma. Gamble and his coworkers (1) pointed out how constant the level of fixed base in the plasma remained during fasting, and indicated to what extent as a result of experimental pyloric obstruction, reciprocal variation of such anions as $\mathrm{Cl}^{\prime}$ and $\mathrm{HCO}_{3}{ }^{\prime}$ could occur without change in the level of total base. One of us (A. F. H.) (2) also emphasized the same fact in a study of pyloric and intestinal obstruction, intestinal fistulae, and marked vomiting of infants and children. Urinary secretion (or lack of secretion) plays the principal rôle in this strict maintenance of plasma electrolyte. When urine secretion is too scanty for this purpose as for instance in cases of anhydremia due to diarrhea (3) the level of total electrolyte in the plasma occasionally reaches enormous values.

It.is the object of this paper to present data obtained from cases of glomerular nephritis with the idea principally of showing: (1) that in acute hemorrhagic nephritis, marked changes in electrolyte and nonprotein nitrogen depend chiefly upon such symptoms as anuria, edema, convulsions and vomiting; (2) that in cases of subacute and chronic 
glomerular nephritis with marked renal injury changes also occur as a result both of retention of acid (chiefly phosphoric and sulfuric, occasionally also hydrochloric) and loss of plasma fixed base, dependent primarily upon the failure of the kidney to excrete acid neutralized by ammonia and secondarily upon a failure of the kidney to secrete urine of the normal maximum acidity; (3) that as total electrolyte diminishes in the plasma, non-protein nitrogen increases so that the osmotic pressure remains normal; (4) that consequently, the alteration in the concentration and composition of plasma electrolyte and not the concentration of non-protein nitrogen should be considered as the more important result of renal insufficiency.

The chemical methods were the same as described previously (2). In an attempt to calculate the equivalent osmolar concentration of the individual electrolytes and non-electrolyte crystalloids from their molar concentration, advantage was taken of the following facts and assumptions:

(1) According to Landolt and Börnstein (4), the molecular lowering of the freezing point of $\mathrm{NaCl}$ is $3.45^{\circ} \mathrm{C}$, which would make the osmolar concentration by volume 1.87 times the molar.

(2) According to the same authors, the molecular lowering of the freezing point of $\mathrm{NaHCO}_{3}$ is $3.59^{\circ} \mathrm{C}$. which would make its osmolar concentration by volume 1.95 times the molar.

(3) The molecular lowerings, according to the same authors, of $\mathrm{Na}_{2}-$ $\mathrm{HPO}_{4}$ and $\mathrm{NaH}_{2} \mathrm{PO}_{4}$ are $5.0^{\circ} \mathrm{C}$. and $3.59^{\circ} \mathrm{C}$ : respectively. If we assume that the ratio $\mathrm{Na}_{2} \mathrm{HPO}_{4} / \mathrm{NaH}_{2} \mathrm{PO}_{4}$ remains $4 / 1$, the osmolar concentration by volume of the serum inorganic phosphate can be calculated by multiplying the concentration of inorganic phosphate in mgm. per cent by the factor 1.02 .

(4) The osmotic effect of the protein we considered as being equivalent to that of undissociated B-protein (calculated by Van Slyke's (5) formula for human blood).

(5) Lactic acid was considered as being present in the form of $\mathrm{Na}$ lactate, with the same degree of dissociation as $\mathrm{NaCl}$. Its osmolar concentration by volume, therefore, would be 1.87 times its molar.

(6) The osmotic effect of non-protein nitrogen was assumed to be due entirely to urea and was calculated on the assumption that 70 per cent of the non-protein nitrogen was urea nitrogen. The remainder was not taken into account. 
(7) The osmotic effect of glucose in terms of osmolar concentration by volume was calculated by the equation milligram glucose per 100 cc. $\times 10 \times 1 / 180$.

In each instance the osmolar concentration by volume was converted to osmolar concentration by weight by applying the correction used by Van Slyke (6) for the volume occupied by the protein. In practice this meant dividing the osmolar millimoles by volume by the factor $0.990-(0.8 \times$ Protein $)$.

No attempt was made to allow for the osmotic effect of sulfate. The usual excess of total base over determined acid was also not taken into account, because of our lack of information as to the nature of such undetermined acid. Inaccuracy is admittedly introduced in the calculation of the osmotic pressure of non-protein nitrogen by our failure to determine urea directly.

On the basis of these assumptions, the normal blood of the young child would be as follows:

\begin{tabular}{|c|c|c|}
\hline & $\begin{array}{l}m M \text {. concen- } \\
\text { tration of } B^{-}\end{array}$ & $\begin{array}{c}\text { Equivalent } \\
\text { osmolar mM } \\
\text { by weight }\end{array}$ \\
\hline $\mathrm{NaCl} 585$ mgm./100 cc.. & . . 100 & 200 \\
\hline $\mathrm{CO}_{2}$ content 55 volumes per cent. & 23.3 & 48.7 \\
\hline pH $7.40 \ldots \ldots \ldots \ldots \ldots \ldots \ldots \ldots \ldots \ldots$ & & \\
\hline Protein 7.00 per cent $\ldots \ldots \ldots \ldots \ldots \ldots \ldots \ldots$ & 14.5 & 15.6 \\
\hline Inorganic $P 5.0 \mathrm{mgm} . / 100 \mathrm{cc} \ldots \ldots \ldots \ldots \ldots \ldots$ & 3.0 & 5.5 \\
\hline Lactic acid $18.0 \mathrm{mgm} . / 100 \mathrm{cc} \ldots \ldots \ldots \ldots$ & 2.0 & 4.2 \\
\hline "Total" acid............. & 143.8 & 274.0 \\
\hline Total base $\ldots \ldots \ldots \ldots \ldots \ldots \ldots \ldots \ldots \ldots \ldots \ldots \ldots$ & 145.0 & \\
\hline Glucose $100 \mathrm{mgm} . / 100 \mathrm{cc} \ldots \ldots \ldots \ldots \ldots \ldots \ldots \ldots \ldots$ & & 6.4 \\
\hline Non-protein nitrogen $30 \mathrm{mgm} . / 100 \mathrm{cc} \ldots \ldots \ldots \ldots \ldots \ldots$ & & 8.0 \\
\hline "Total" non-electrolyte $\ldots \ldots \ldots \ldots \ldots \ldots \ldots \ldots \ldots \ldots$ & & 14.4 \\
\hline "Total" acid plus non-electrolyte $\ldots \ldots \ldots \ldots \ldots \ldots$ & & 288.0 \\
\hline
\end{tabular}

The average lowering of the freezing point of normal serum of children is about $0.570^{\circ} \mathrm{C}$. The equivalent osmolar concentration would be 310 millimoles. The total theoretical osmolar concentration of the normal serum is, therefore, 93.0 per cent of the observed. Electrolyte furnishes 95 per cent of the total theoretical osmotic pressure, the remainder being due chiefly to urea and glucose. The small fraction unaccounted for is presumably due largely to electrolyte as indicated by the excess of total base over the sum of the five individual acids determined. 


\section{ACUTE HEMORRHAGIC NEPHRITIS}

\section{Protocols}

Cases 1 to 16, inclusive: These cases were typical uncomplicated cases of acute hemorrhagic nephritis, without uremia, marked edema, or marked vomiting.

Case 17. Cletus B. Age, 9 years. This patient was admitted on May 12, 1927. Three weeks previously edema was noted, which steadily increased. $\mathrm{He}$ complained of headache, nausea, vomited occasionally and during the night before admission had two generalized convulsions. When admitted he was quite drowsy. There was general anasarca. His blood pressure was $187 / 100 \mathrm{~mm}$. Hg. There was moderate fever and leucocytosis. The mucous membrane of his nose was reddened, particularly over the left middle turbinate. The tonsils were enlarged and red. Frequent convulsions occurred during the first twenty-four hours, despite the free use of sedatives. A very small amount of urine, containing many red blood cells, leucocytes and casts was passed during this period. Two hundred fifty cubic centimeters of 20 per cent glucose were given intravenously, and there followed a very marked improvement. Convulsions ceased, diuresis occurred, edema was rapidly lost, the urine cleared and on May 17 when the patient left the hospital there was only a faint albuminuria.

Case 18. Rose M. Age, 14 years. This patient had been well until about two weeks before hospital admission on March 28, 1928. She then became ill with fever, cough and headache. A week later edema of her face, feet and abdomen were noted. This edema largely subsided after about four or five days. Her urine was not examined during that time. On March 27 three generalized convulsions occurred, each lasting several minutes. When first seen at the hospital she was without edema, fever or other signs of acute infection, but much disoriented. Her blood pressure was $162 / 108 \mathrm{~mm}$. Hg. Her urine showed considerable albumin and many red blood cells, white blood cells and casts. Two more generalized convulsions occurred before blood was taken for chemical examination. One hundred forty cubic centimeters of 1 per cent magnesium sulfate solution were then given intravenously, after which she became quiet and had no more convulsions. The blood pressure gradually returned to normal by April 5. On April 14 the urine was free from albumin and blood cells and showed but an occasional cast and the patient was discharged.

Case 19. Tom F. Age, 5 years. Except for frequent colds, this patient was well until about October 8, 1926, when edema of the eyelids was noted. A few days later, the scrotum became edematous, and on October 20 he was admitted to the hospital. He then had generalized edema and ascites. The urine contained a large amount of albumin and many leucocytes and red blood cells. His tonsils and adenoids were hypertrophied and infected, pus was present in the nose and 
there was $x$-ray evidence of maxillary sinusitis. Because the clinical picture was that of nephrosis rather than acute hemorrhagic nephritis, he was given a high caloric, high protein diet without restriction of fluid. Edema disappeared and the urine gradually cleared. On November 26 the tonsils and adenoids were removed. Gross hematuria and slight edema followed. Later otitis media developed, with $\mathrm{x}$-ray evidence of mastoiditis. His general condition improved, however, the temperature became normal, the urine cleared and the discharge from the ear ceased without mastoidectomy. He was discharged on January 21,1927 with only a faint trace of albumin in the urine.

Case 20. William J. Age, 5 years. This patient had been well until October 15, 1927, when he developed a mild scarlet fever. About three weeks later, November 6, he became drowsy and vomited several times. On the following two days there was marked suppression of the urine. On November 9, there was complete anuria, which persisted up to and also on November 10, the day of admission to the hospital. On the same day vomiting continued and a puffiness of his face was noticed. When first seen in the hospital he did not appear acutely ill. There was a slight edema of his face, feet and ankles. There was apparently no urine in the bladder. After chemical study of his blood, $500 \mathrm{cc}$. of Ringer's solution were given intraperitoneally and $675 \mathrm{cc}$. of 20 per cent glucose intravenously. He was given water and fruit juices without restriction and a quart of milk daily. On November 11 urinary output was $18 \mathrm{cc}$; on November 12, 49 cc.; on November 13, 92 cc.; on November 14, 158 cc.; on November 15, 215 cc. and from that time on his output continued to increase. Up to December 11 the urine contained a small amount of blood and a trace of albumin; then blood and albumin disappeared from the urine. On December 1 he developed pneumonia with pleurisy, from which he recovered a week or so later. He was discharged on December 14, well.

Case 21. Catherine B. Age, 9 years. Admitted to the hospital on April 8, 1926. From the age of 2 months the patient had frequent recurrent attacks of otitis media, with spontaneous rupture of the drums and foul smelling, purulent discharge, continuing for varying lengths of time. Two weeks before admission, otitis media again recurred, and the left drum ruptured spontaneously. Irregular fever, however, continued and vomiting became a very pronounced symptom. Three days before admission the urine was found to contain gross blood.

When admitted to the hospital, the patient was found prostrated, much underweight, pale and moderately anhydremic. She complained of nausea, and promptly vomited practically everything taken by mouth. Chronic bilateral otitis media, with superimposed subacute otitis media on the left was present. In addition, pus was found in the nose and the lymph nodes in the anterior and posterior cervical triangles were enlarged. X-ray indicated mastoiditis on the left side and bilateral maxillary sinusitis. The urine showed gross blood, considerable albumin and many casts. The pronounced chemical changes in the 


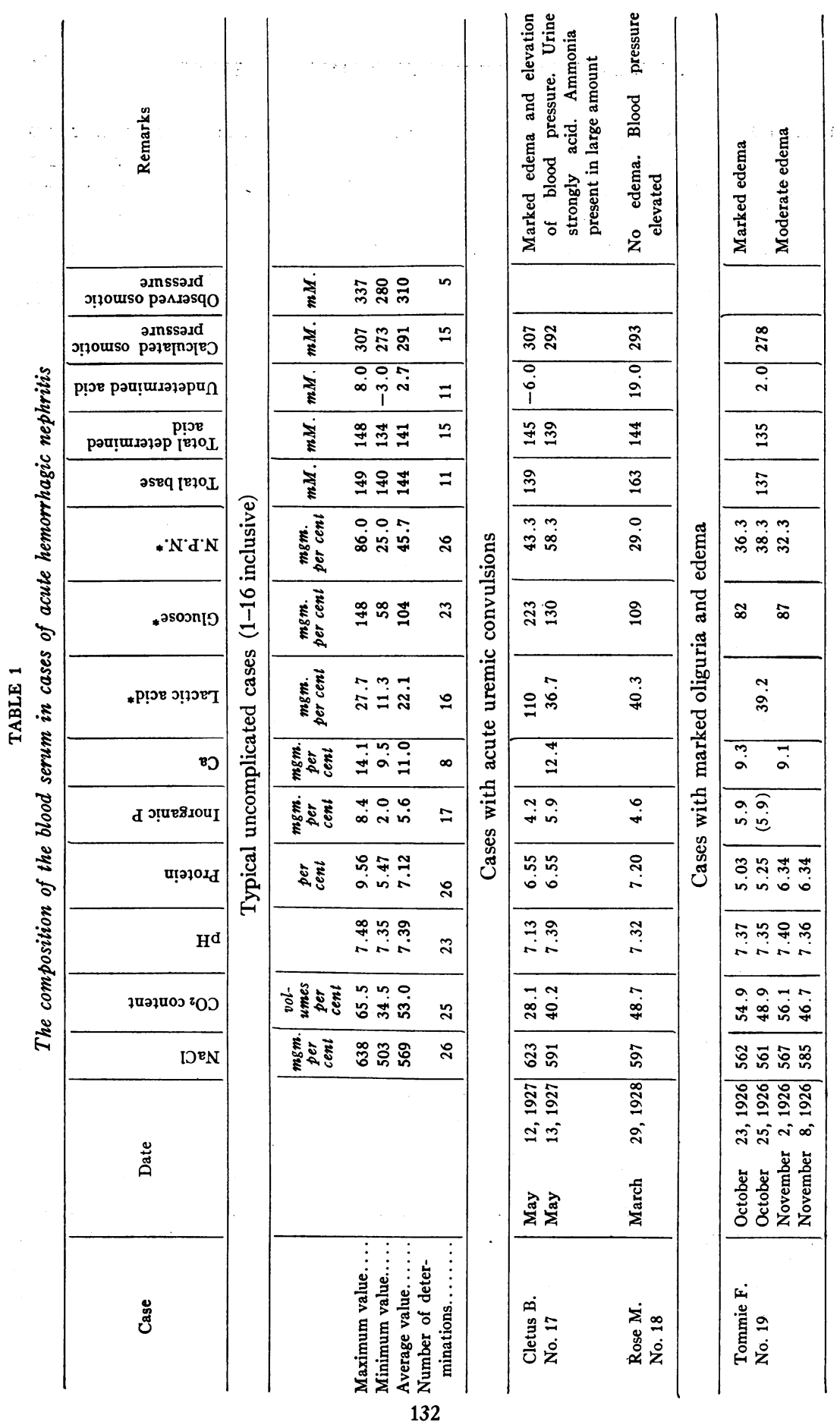




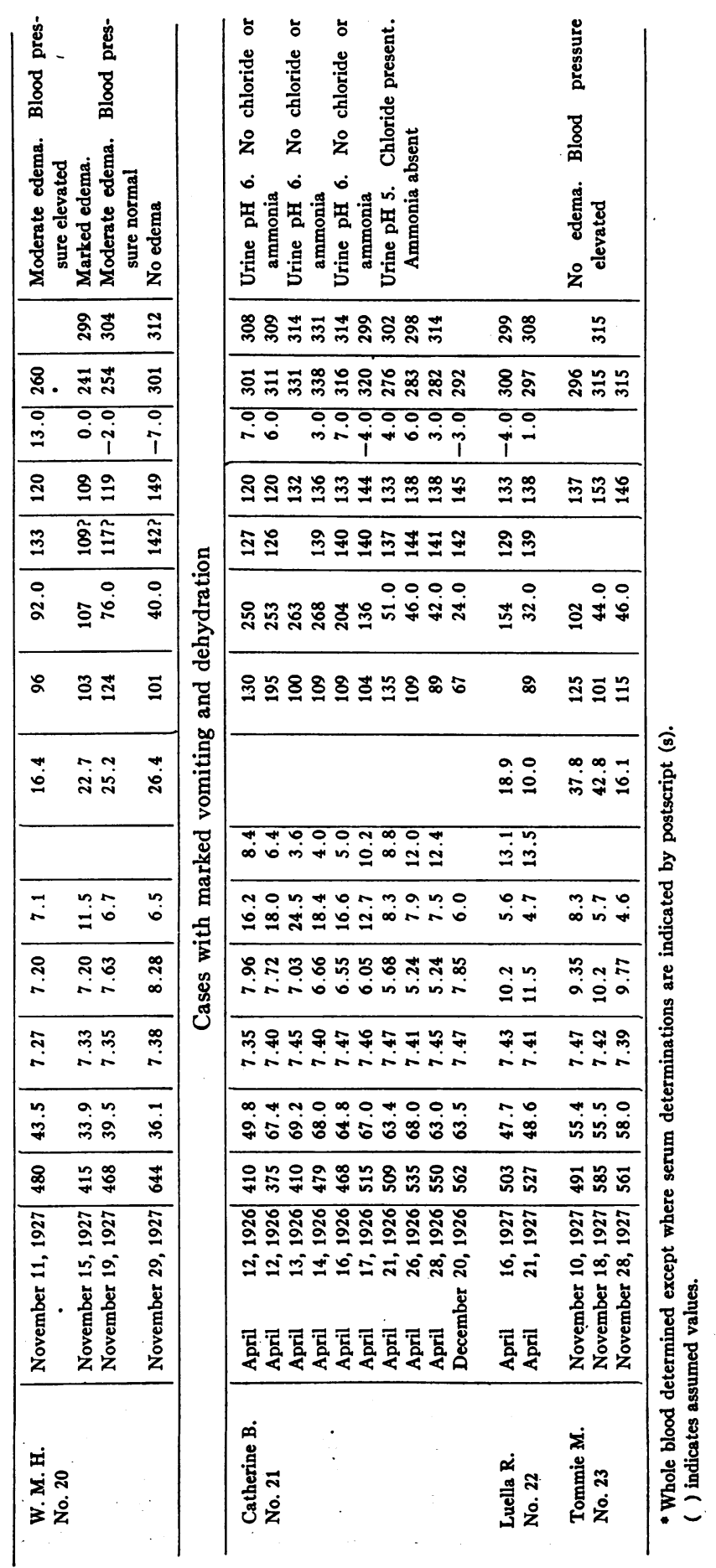


blood are shown in table 1 and chart 1 . During the next five days, there was irregular fever, the temperature fluctuating from $37^{\circ} \mathrm{C}$. to $39.3^{\circ} \mathrm{C}$. The leucocyte count rose from 10,800 on admission to 21,000 on April 14. Persistent vomiting continued. On April 14, both antra were irrigated, pus being washed out, and the left mastoid was opened, pus also being found. From both the mastoid and the blood stream Streptococcus hemolyticus was cultured. Following mastoidectomy vomiting ceased immediately. A marked skin eruption of the erythema multiforme type appeared. The patient's condition steadily improved, despite the fact that the septicemia persisted until April 20 and that an abscess, probably embolic, developed in the chest wall. Following tonsillectomy and adenoidectomy on May 21, fever and gross hematuria recurred, lasting for a week. The maxillary antra were treated by repeated irrigations. The patient was then sent to the country department of the hospital for convalescence. There her temperature became normal, her urine cleared completely, and she gained 30 pounds in weight in 9 months.

Therapy directly influencing the composition of the blood studied was as follows:

On April 12, after the first blood sample was obtained, $900 \mathrm{cc}$. of Ringer's solution were given intraperitoneally, and $400 \mathrm{cc}$. of 10 to 20 per cent glucose intravenously. After the second blood sample on the same day, $1500 \mathrm{cc}$. of Ringer's solution and $100 \mathrm{cc}$. of glucose were given. On April 14, $400 \mathrm{cc}$. of Ringer's sollition were given intraperitoneally and $250 \mathrm{cc}$. of glucose solution intravenously: On April 15, 175 cc. of blood, and on April 21, 180 cc. of blood were given intravenously.

Case 22. Luella R. Age, 5 years. This patient was admitted on December 3,1921 . A month previously, she had complained of earache and had rever. A week before admission there was a spontaneous rupture of one ear drum. Hematuria and marked vomiting were present for three days before admission. On admission, the patient was desiccated and had slight fever. The urine contained gross blood, much albumin and many casts. The tonsils were large and ragged and the left ear was discharging pus through a good sized perforation. With rest in bed and restricted diet, the general condition improved, the urine cleared, and on April 22 the tonsils and adenoids were removed.

Case 23. Tommie M. Age, 6 years. This patient had been well until he was injured during a tornado in the latter part of September, 1927. He received many skin wounds, which later became infected. About the first of November, blood was noted in his urine, slight fever was present and vomiting became very marked. A week later, November 8, 1927, he was admitted to the hospital. He was found to be undernourished and with several infected skin wounds and many scars of wounds already healed. The tonsils were ragged and red and there was considerable pus seen in his nose. His urine showed gross blood and a large amount of albumin. With rest in bed and restricted diet, his urine gradually cleared and became negative on December 12, at which time he was discharged on a regular diet. 


\section{The typical uncomplicated cases}

In general, as can be noted in table 1, the chemical changes of the blood encountered in typical uncomplicated cases of acute hemorrhagic nephritis were of small magnitude, and in this respect were in agreement with the observations of Blackfan and Hamilton (7). Chloride varied in both directions from the normal, but averaged slightly

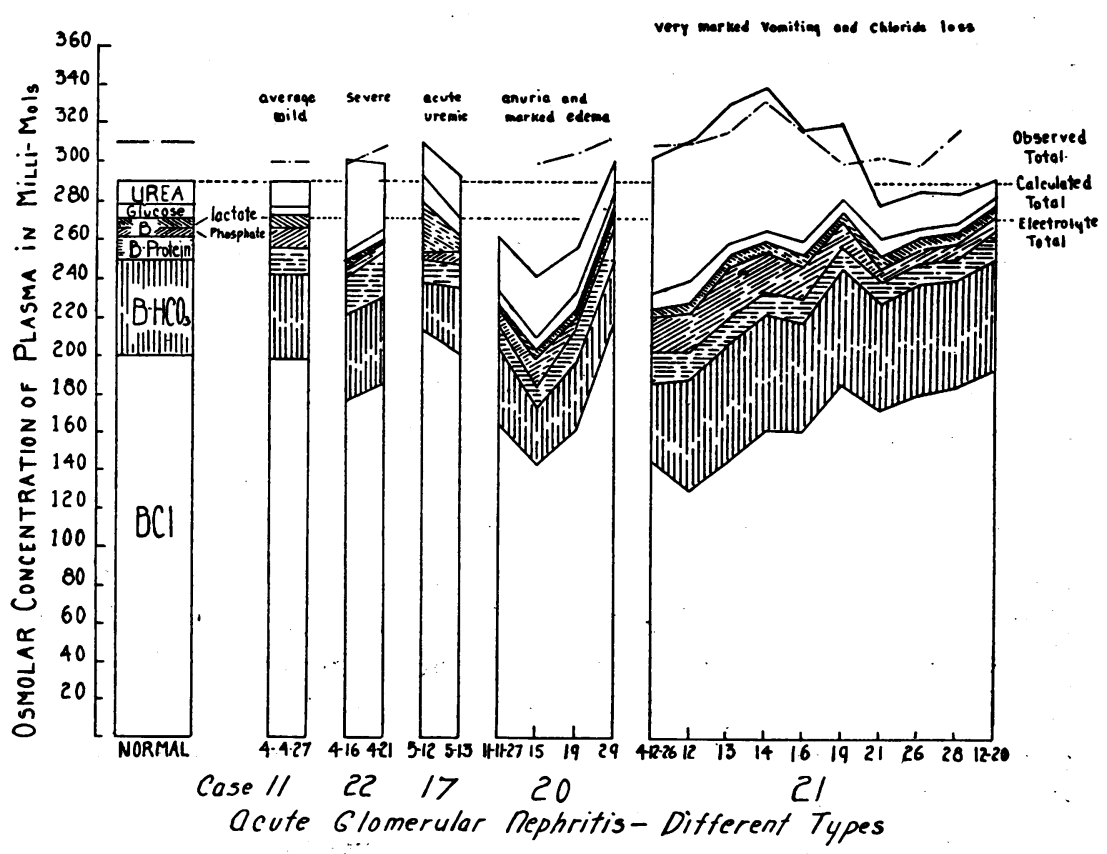

Chart 1. The Osmolar Concentration of the Principal Electrolyte and Non-Electrolyte Crystalloms in the Serum of Cases of Acute HEMORRHAGTC NEPHRITIS

low, $97.3 \mathrm{mM}$. Bicarbonate also varied in both directions, but averaged $22.5 \mathrm{mM}$., a low normal value. The $\mathrm{pH}$ varied very little, and averaged 7.39. Protein varied considerably, the lowest value being 5.47 per cent and the highest 9.56, averaging 7.12, a normal value. Inorganic phosphate also varied both ways, but averaged $5.6 \mathrm{mgm}$. per cent, a high normal value. Calcium varied little and averaged normal. Lactic acid did not exceed $27.7 \mathrm{mgm}$. per cent, and averaged 
22.1. Glucose varied from 58 to $148 \mathrm{mgm}$. per cent. Total base varied only from 140 to 149 , averaging $144 \mathrm{mM}$. "Total" acid $(\mathrm{Cl}+$ $\mathrm{HCO}_{3}+$ protein $+\mathrm{HPO}_{4}$ + lactic acid) varied somewhat more, from 134 to $148 \mathrm{mM}$., averaging 141 . Undetermined acid varied from -3.0 to 8.0 , averaging $2.7 \mathrm{mM}$. By freezing point determinations, in five instances the osmotic pressure averaged $310 \mathrm{mM}$., varying between 280 and 337. The calculated osmotic pressure varied from 273 to 307 , averaging $291 \mathrm{mM}$., or 94.0 per cent of the average determined osmotic pressure, a normal relationship. Non-protein nitrogen varied from 25 to $86 \mathrm{mgm}$. per cent, averaging 45.7 .

\section{Cases with acute uremic convulsions}

Case 17, whose blood was studied shortly after uremic convulsions had occurred, showed a marked "acidosis." The $\mathrm{BHCO}_{3}$ content was reduced by $11 \mathrm{mM}$. and was almost exactly equalled by the 10.2 $\mathrm{mM}$. increase in lactic acid. The $\mathrm{pH}$ had dropped to 7.13. $\mathrm{BCl}$ was increased by $7 \mathrm{mM}$. There was also hyperglycemia, the glucose content being $223 \mathrm{mgm}$. per cent. On the next day, with cessation of convulsions, there was noted an increase in $\mathrm{BHCO}_{3}$ of $5.1 \mathrm{mM}$. with a decrease of $8.1 \mathrm{mM}$. lactic acid and $6 \mathrm{mM}$. BCl. As calculated, about $6 \mathrm{mM}$. electrolyte had left the blood stream. Diuresis had not yet begun, and edema was apparently increasing during this period. The lactic acid "acidosis" in this instance undoubtedly occurred as a result of the convulsions and anoxemia present at and before the time that the blood was studied.

Case 18 was a similar case and similarly showed decrease in $\mathrm{BHCO}_{3}$ and increase in lactic acid. An unusually high value for undetermined acid, $19.0 \mathrm{mM}$., was indicated, however. Total base in this instance was unusually high, and may have been in error, and such a large quantity of undetermined acid may not really have existed.

It is rather interesting to note that in Case 17 the non-protein nitrogen during the acute uremic manifestations was but $43.3 \mathrm{mgm}$. per cent, and in Case 18 but 29 mgm. per cent.

\section{Cases with marked oliguria and edema}

Case 19, when admitted was at first mistaken for nephrosis. Edema and albuminuria were very marked, and there was neither non-protein 
nitrogen retention nor elevation of blood pressure. The chief abnormal blood findings were low plasma protein and slightly diminished calcium, total base and "total" acid. In these respects the blood findings were similar to those usually found in nephrosis. The hematuria which followed immediately after tonsillectomy and the later complete recovery from all edema and albuminuria in a relatively short time made us feel that the case was one of subsiding acute glomerular nephritis accompanied by unusually marked edema and albuminuria.

Case 20 is also of special interest because of the changes associated with very pronounced suppression of urinary secretion. On admission on November 11,1927, after four days of almost complete suppression, $\mathrm{BCl}$ was found reduced by $18 \mathrm{mM}$., $\mathrm{BHCO}_{3}$ by about $4 \mathrm{mM}$., while lactic acid and protein were normal and phosphoric acid increased by only $1.1 \mathrm{mM}$. equivalent univalent base. The total base, although reduced, was relatively high, exceeding the "total" acid determined by $13 \mathrm{mM}$., thus indicating the presence of considerable undetermined acid. Non-protein nitrogen was rather markedly increased, however. Without consideration of the apparently large amount of undetermined acid, the osmolar concentration of the determined acids plus glucose and urea was lower than the normal (see chart 1). Four days later, on November 15, despite salt solution administration and continued anuria, $\mathrm{BCl}$ and $\mathrm{BHCO}_{3}$ were still further reduced. At this time, however, there was noted an appreciable increase in phosphoric acid. The "total" acid determined, however, was extremely low, and agreed very closely with total base, indicating either that one of the two of the total base values was in error, or that the hitherto appreciable amount of undetermined acid had disappeared from the blood. The observed freezing point was normal. The theoretical osmolar concentration calculated from the determined acids, urea, and glucose was only 80.6 per cent of the observed. This discrepancy, if not due to experimental error, would indicate the presence of some undetermined osmotically active substance. We are inclined to question the unusually low value for total base and believe this undetermined osmotically active substance was largely electrolyte.

On November 19 after the establishment of urinary secretion, a decided tendency for return toward normal of individual electrolytes 
as well as non-protein nitrogen was noted. On November 29, however, a few days after a decided diuresis with loss of edema fluid had begun, an interesting chemical picture was noted: $\mathrm{BHCO}_{3}$ was still reduced, but $\mathrm{BCl}$ was decidedly higher than normal. Total acid was slightly above the normal and non-protein nitrogen had dropped almost to the normal value. A normal freezing point at this time was observed and agreed well with the calculated one.

\section{Cases with marked vomiting and dehydration}

Case 21 was admitted after two weeks of marked vomiting and one week of hematuria, the results of a hemolytic streptococcic infection of one mastoid and both maxillary antra. Severe dehydration was present. The blood picture on admission was extremely interesting. $\mathrm{BCl}$ was greatly reduced, being but $71 \mathrm{mM} . \quad \mathrm{BHCO}_{3}$ was of a low normal concentration, $21.0 \mathrm{mM}$. The $\mathrm{pH}$ was 7.35. Protein concentration was 7.96 per cent, as compared with 5.24 per cent following restoration of a normal fluid balance, thus indicating marked water loss from the plasma. Inorganic phosphate was very much increased and calcium considerably decreased. Total base was also considerably reduced, $127 \mathrm{mM}$., and exceeded "total" acid by $7.0 \mathrm{mM}$. The undetermined acids were presumably sulfuric and lactic. The total electrolyte osmolar concentration as calculated was only $227 \mathrm{mM}$. Non-protein nitrogen, however, was so elevated (250 mgm. per cent) that the total osmolar concentration as calculated was $301 \mathrm{mM}$. in very good agreement with the observed freezing point indicating a concentration of $308 \mathrm{mM}$. The administration of $900 \mathrm{cc}$. of Ringer's solution and $400 \mathrm{cc}$. of 10 per cent glucose on the day of admission effected a considerable dilution of the plasma, judging from the fall of plasma protein from 7.96 to 7.03 per cent, but vomiting persisted and $\mathrm{BCl}$ remained low, while $\mathrm{BHCO}_{3}$ increased to $28.1 \mathrm{mM}$. Inorganic phosphate reached the enormous value of $24.5 \mathrm{mgm}$. per cent, and calcium the low value of $3.6 \mathrm{mgm}$. per cent. The total electrolyte osmolar concentration was little altered, being but $230 \mathrm{mM}$. and the non-protein nitrogen remained elevated. As before, the freezing point indicated a normal osmotic pressure (309 mM.)

With further administration of Ringer's solution, there occurred an increase in $\mathrm{BCl}$ to $810 \mathrm{mM}$. on April 14 sufficient to raise the elec- 
trolyte osmolar concentration to $260 \mathrm{mM}$., making the total calculated osmolar concentration $338 \mathrm{mM}$. The freezing point indicated an osmolar concentration of $331 \mathrm{mM}$. There was, therefore, a distinct rise in osmolar concentration. There then occurred a marked reduction in non-protein nitrogen concentration, which must have been due to secretion into the urine. That such increase in urea secretion was not due to any spontaneous improvement in the patient's condition was indicated by the fact that she was vomiting as much as previously, had not as yet had her mastoid drained, had still a septicemia and apparently was not secreting any larger quantities of urine. Further increase in $\mathrm{BCl}$ concentration which occurred with the immediate cessation of vomiting after mastoidectomy later on April 14 was followed also by continued reduction in the non-protein nitrogen concentration and by April 28 the blood was again practically normal in all respects.

In most respects the blood of this patient showed changes similar to those seen in the cases of severe chronic nephritis described later. There was, however, no $\mathrm{BHCO}_{3}$ decrease but in fact usually a slight increase. We are, therefore, inclined to feel that vomiting and not faulty urinary secretion was instrumental in causing chloride loss, permitting $\mathrm{BHCO}_{3}$ to remain even higher than normal despite considerable increase in phosphoric and undetermined acid.

Case 22 was similar to Case 21, a low total base concentration of $129 \mathrm{mM}$. due chiefly to $\mathrm{BCl}$ loss, resulting in reduction of total electrolyte osmolar concentration to $252 \mathrm{mM}$. Non-protein nitrogen increase to $154 \mathrm{mgm}$. per cent was sufficient to maintain a theoretical total osmolar concentration of $300 \mathrm{mM}$. The observed freezing point indicated a concentration of $299 \mathrm{mM}$. Later, as total base increased to $139 \mathrm{mM}$., non-protein nitrogen decreased to normal, and the osmotic pressure was still normal both as calculated and observed.

This case was also of interest because of the enormous increase of serum protein to 10.2 and 11.5 per cent. Despite such marked anhydremia there occurred increase in neither phosphoric nor lactic acid.

Case 23 was very similar to case 22, showing marked anhydremia with, however, phosphoric and lactic acid increase. As in both case 21 and 22, the initial low electrolyte concentration was balanced osmotically by non-protein nitrogen increase. 


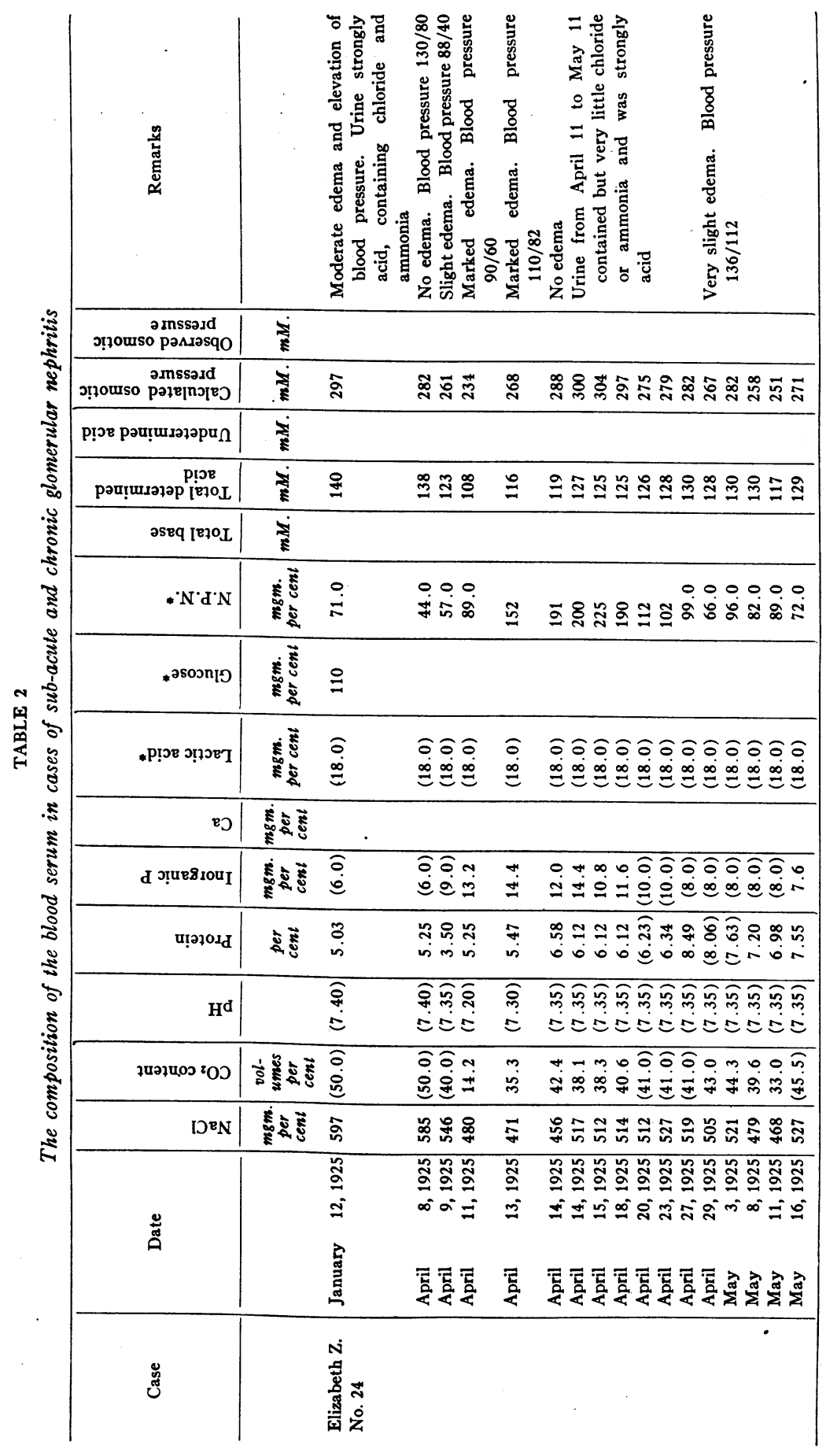




\begin{tabular}{|c|c|c|}
\hline 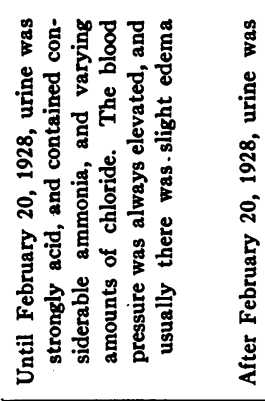 & 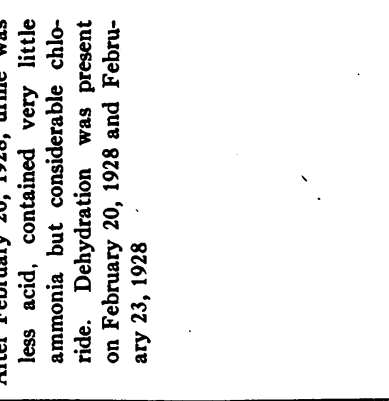 & 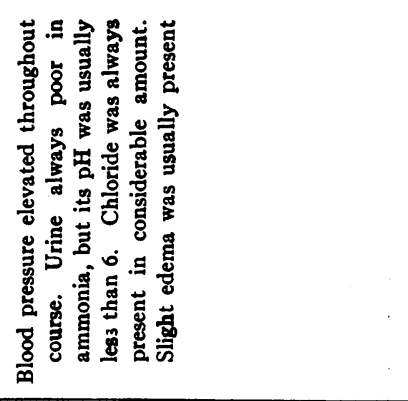 \\
\hline & 欱品 & \\
\hline : & 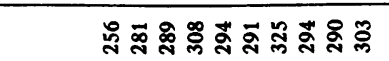 & 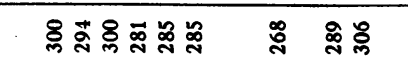 \\
\hline & $\begin{array}{l}0 \\
\text { i }\end{array}$ & \\
\hline$\cong$ & 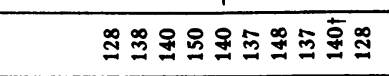 & 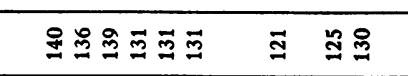 \\
\hline & 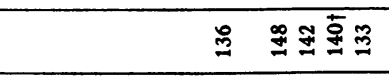 & \\
\hline 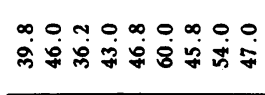 & 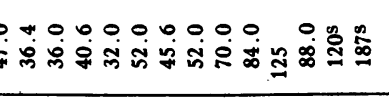 & 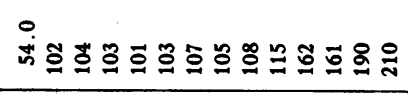 \\
\hline$\stackrel{8}{\Xi 2} \cong \Xi$ & 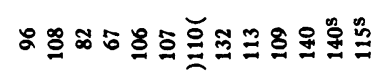 & 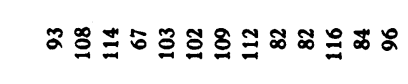 \\
\hline 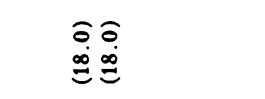 & 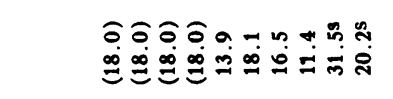 & 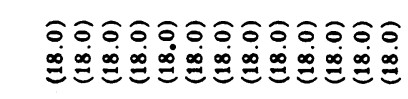 \\
\hline$\stackrel{n}{n}$ & 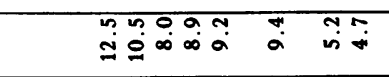 & 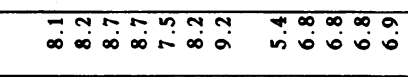 \\
\hline 움 & 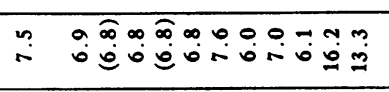 & 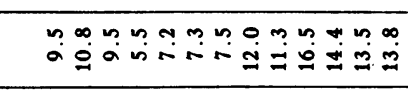 \\
\hline 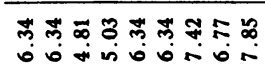 & 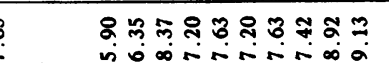 & 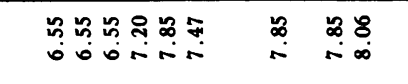 \\
\hline 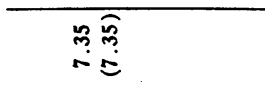 & 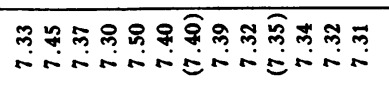 & 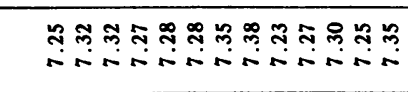 \\
\hline 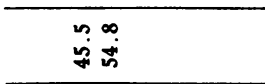 & 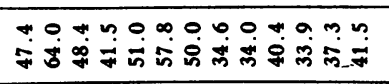 & 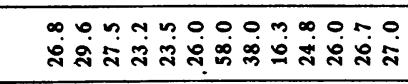 \\
\hline 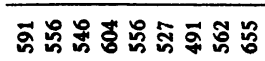 & 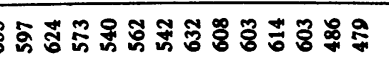 & 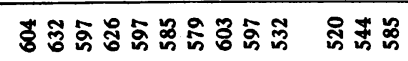 \\
\hline 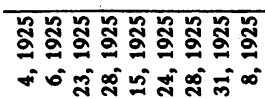 & 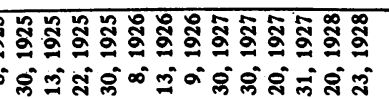 & 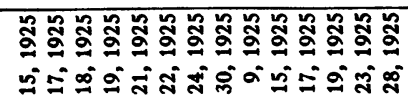 \\
\hline 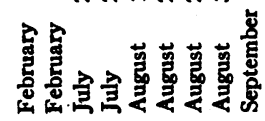 & 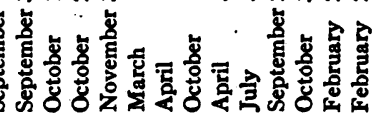 & 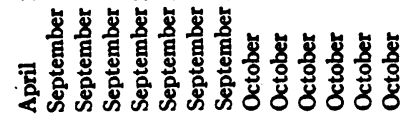 \\
\hline 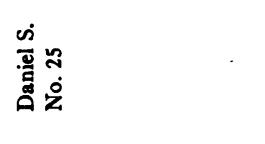 & & 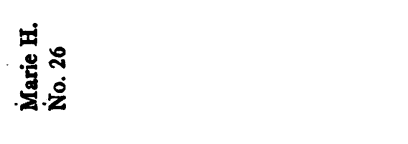 \\
\hline
\end{tabular}




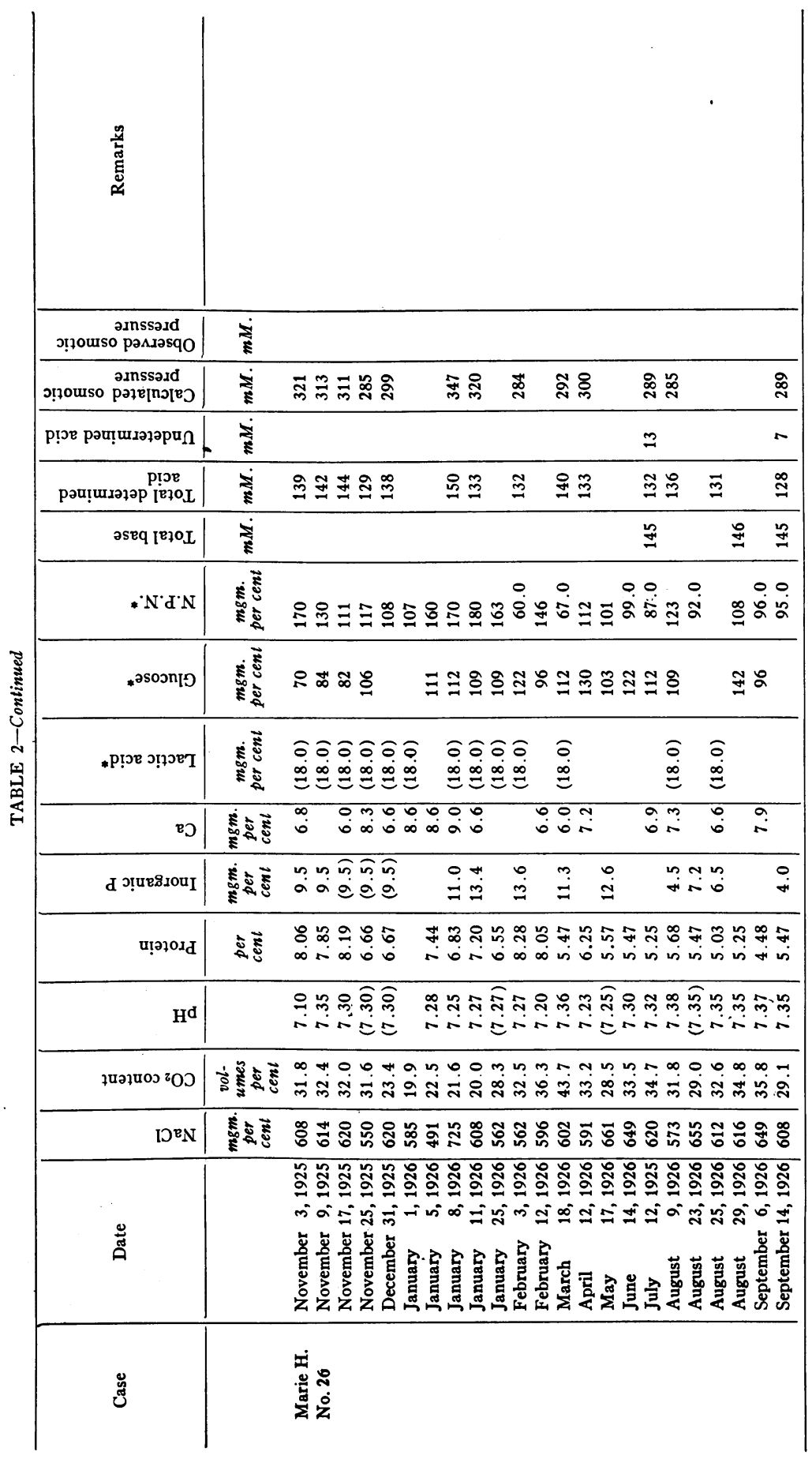




\begin{tabular}{|c|c|c|c|c|c|c|}
\hline 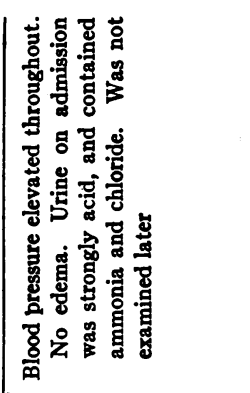 & 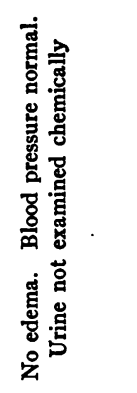 & 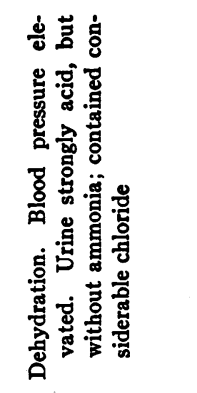 & 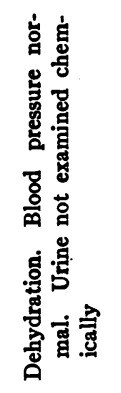 & 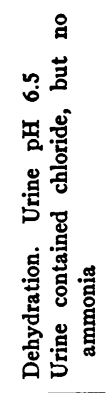 & 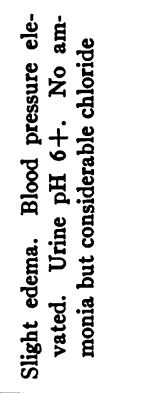 & 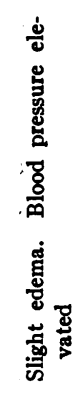 \\
\hline ః्లె & & & & & 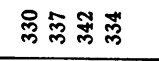 & ల్లె \\
\hline 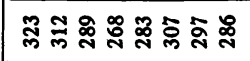 & 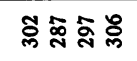 & 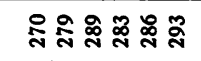 & 总尽足 & ธู่ & 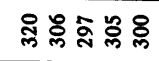 & बे \\
\hline 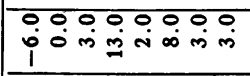 & 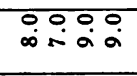 & & $\begin{array}{ll}\circ \\
\infty\end{array}$ & $\because \div$ & $\stackrel{\circ}{i}+i$ & \\
\hline$\tilde{్}$ & 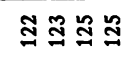 & 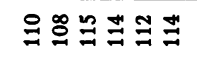 & $\Xi \Xi \cong$ & 焉 & 总品 & \pm \\
\hline 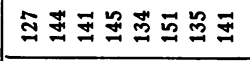 & 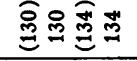 & & సి ฐ & 9 & 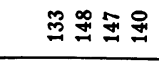 & \\
\hline 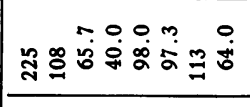 & 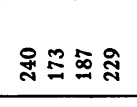 & 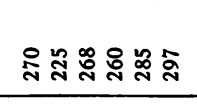 & 虽是号 & 点 & 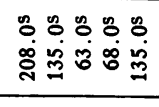 & 总 \\
\hline 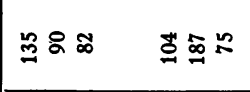 & $\approx \infty$ & 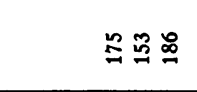 & $\exists \Xi \Xi$ & 串高 & 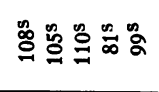 & 战 \\
\hline 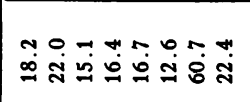 & & & فํ. & 总 & 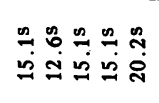 & $\stackrel{ٌ}{\Leftrightarrow}$ \\
\hline 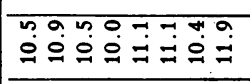 & 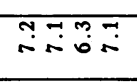 & & $\stackrel{n}{n}$ & & क्ष & \\
\hline 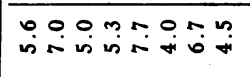 & 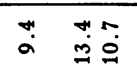 & 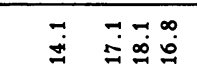 & 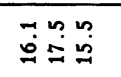 & $\stackrel{\circ}{i}+\dot{i}$ & 管 & $\stackrel{\circ}{\circ}$ \\
\hline 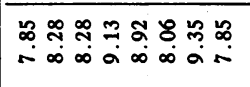 & 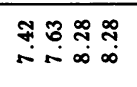 & & 赵萬 & 趈 & 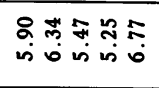 & 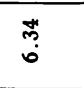 \\
\hline 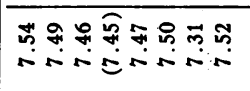 & 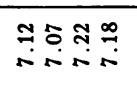 & 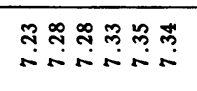 & 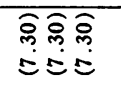 & $\stackrel{\substack{\widehat{S}\\
}}{=}$ & 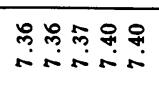 & $\stackrel{\hat{m}}{n}$ \\
\hline 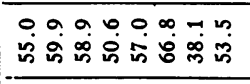 & 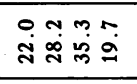 & 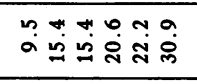 & 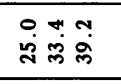 & 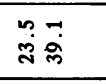 & 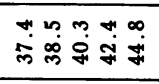 & 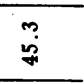 \\
\hline 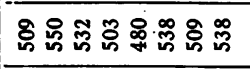 & 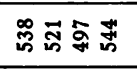 & 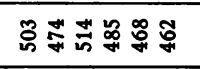 & 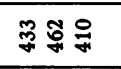 & 웅 & 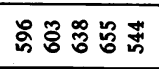 & 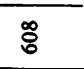 \\
\hline 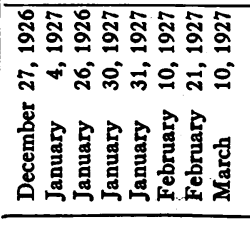 & 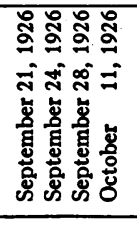 & 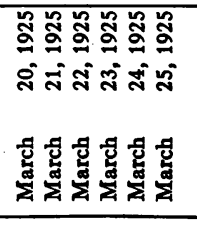 & 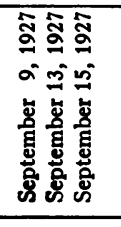 & 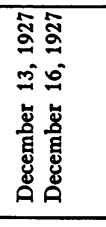 & 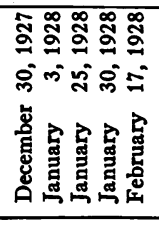 & 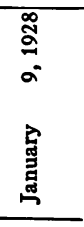 \\
\hline 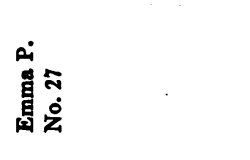 & 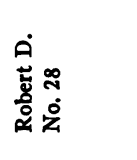 & 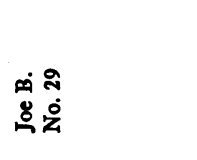 & 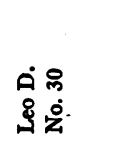 & 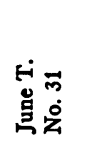 & 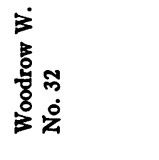 & 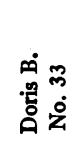 \\
\hline & & 140 & & & & \\
\hline
\end{tabular}




\begin{tabular}{|c|c|c|c|c|c|}
\hline 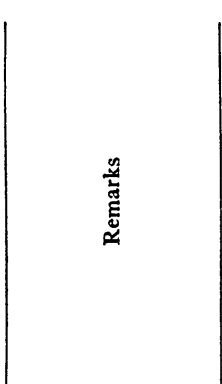 & & 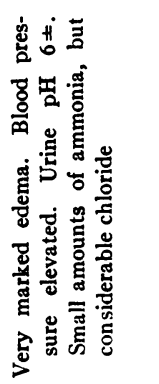 & & 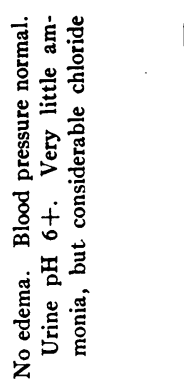 & \\
\hline 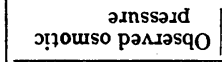 & ז & 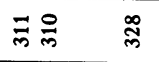 & & 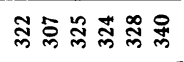 & \\
\hline 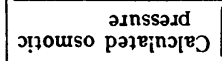 & ह & 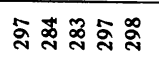 & శ్లి & 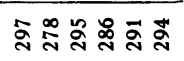 & \\
\hline ргэв рәшішдәэәри & 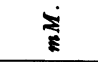 & & & $=2 \infty \rho \infty$ & \\
\hline 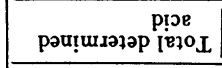 & $\ddot{E}$ & 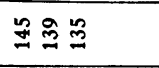 & $\Xi$ & 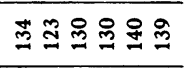 & \\
\hline 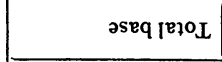 & $\vec{z}$ & 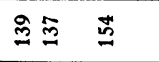 & & 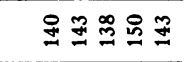 & \\
\hline$* \mathrm{~N} \cdot \mathrm{d} \cdot \mathrm{N}$ & 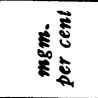 & 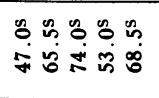 & $\stackrel{\leftrightarrow}{\varrho}$ & 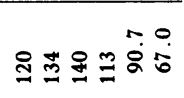 & \\
\hline *2sosn[9 & 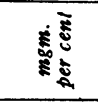 & 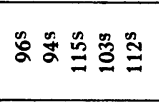 & & 요 & \\
\hline 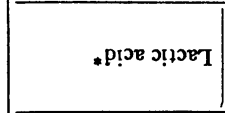 & 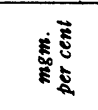 & 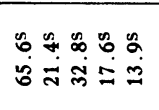 & $\stackrel{m}{m}$ & 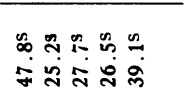 & \\
\hline Eב & (5) & å & $a$ & $\exists \stackrel{\infty}{=} \stackrel{0}{=}$ & \\
\hline 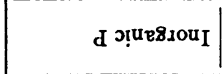 & E: है & a웅요 & $\stackrel{\ddot{b}}{\ddot{\omega}}$ & 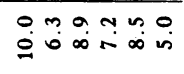 & \\
\hline 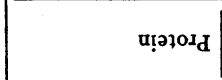 & \& & 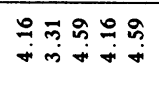 & $\stackrel{\infty}{\infty}$ & 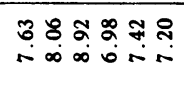 & \\
\hline $\mathrm{H}^{\mathrm{d}}$ & & 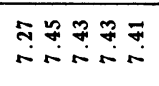 & $\stackrel{m}{n}$ & 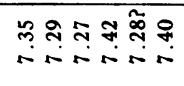 & \\
\hline зиวұนоз г $\mathrm{OJ}$ & 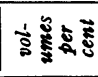 & 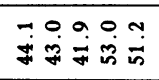 & $\ddot{9}$ & 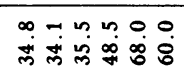 & \\
\hline Den & Eะ & 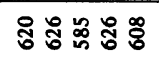 & $\stackrel{\infty}{\infty}$ & 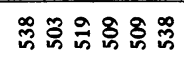 & \\
\hline 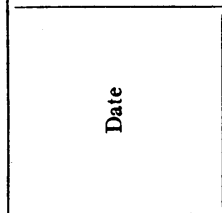 & & 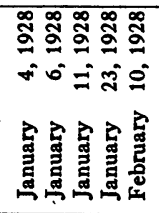 & 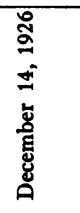 & 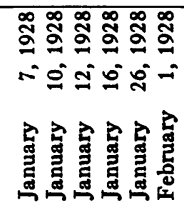 & \\
\hline లే & & 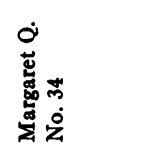 & 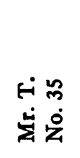 & 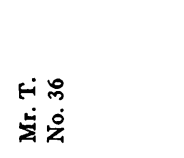 & \\
\hline
\end{tabular}




\section{SUBACUTE AND CHRONIC NEPHRITIS}

\section{Protocols}

Case 24. Elizabeth Z. Age, 12 years. Admitted to the hospital on January 11, 1925. For three years prior to admission this girl frequently suffered from "head colds" and sore throat, and during the last year seemed to her parents to have been abnormally pale- "waxy" as they described her color. During the six months just preceding admission, her weight had increased from 80 to 106 pounds and one month before admission definite edema of the face and ankles was noted. At this time albumin was found in the urine; no hematuria was noticed. Her systolic blood pressure, however, was $140 \mathrm{~mm}$. Hg. During the two weeks before admission she lost 9 pounds in weight.

When admitted, there was a marked waxy pallor of the skin and moderate generalized edema. The urine contained a large amount of albumin, many hyalin casts, leucocytes and red blood cells. The capillary loops of the nail bed showed irregular constrictions in the arterial portions and marked enlargement and tortuosity of the venous limbs. The eye grounds were normal. The blood pressure was $136 / 90 \mathrm{~mm}$. Hg. The red blood cell count was $3,750,000$. The white blood cell count was 9,600 with a normal differential count. Chemical data at this time and subsequently are to be found in table 2, chart 2 . The tonsils were small and ragged and an enlarged mass of adenoids was present. Pus was seen anteriorly and posteriorly in the nose and pansinusitis was diagnosed independently by two nose and throat consultants.

Rest in bed and Karell diet and transfusions were instituted. Gradually edema disappeared and the blood pressure became normal. Hematuria, variable in amount, persisted. Adenoidectomy and tonsillectomy were performed and the nose was treated with mercurochrome drops. Later, stringy muco-pus, from which, however, no organisms grew, was washed from the maxillary antra. Gradually the urine became free from blood, still showing, however, large amounts of albumin and the patient, with increased diet, gained weight and improved generally until April 8, when a nose and throat examination gave evidence of an exacerbation of the infection in the paranasal sinuses. That night, following a chill, the patient vomited, and complained of headache and backache. The temperature, which had been normal, rose sharply to $40.2^{\circ} \mathrm{C}$. The next morning there was noticeable edema. The left border of the heart was found out to the nipple line and the rate was rapid and the impulse weak. The blood pressure fell to 88/40 $\mathrm{mm}$. Hg. from $130 / 86 \mathrm{~mm}$. $\mathrm{Hg}$. The white.blood cell count had increased to 24,300 . Throughout the day the temperature remained elevated, and the patient continued to complain of occipital headache. Urine obtained in small amount by catheterization was cloudy from hyalin and granular casts. It contained a large amount of albumin, as usual, but very few red blood cells. The next day (April 10) the patient complained of abdominal pain and had one green diarrheal stool. During the following day the patient vomited considerably and had four diarrheal 
stools. On April 12 the patient was irrational and had incontinence of feces, and edema seemed a little less. The abdomen was tender and spastic. Red areas, later breaking down and showing a hemolytic streptococcus on culture appeared on one foot and knee. Hemolytic streptococci also grew from a blood culture the following day. The blood pressure by this time had increased to 108/86. Following intravenous glucose, the urinary output increased. On April 14, the patient looked gaunt of face, and edema elsewhere had disappeared, water being lost by vomiting, diarrhea, and slight diuresis. From this time until May 2 the patient gradually improved, receiving six transfusions and intravenous glucose as therapy. The embolic abscesses were opened and drained. The temperature, swinging from $38^{\circ} \mathrm{C}$. to $40^{\circ} \mathrm{C}$. very gradually fell to normal on May 2. At this time, with very little warning, convulsions and stupor manifested themselves. Following the use of magnesium sulphate, intramuscularly, and other sedatives, uremic manifestations disappeared. From this time until May 20, when the patient was taken home, an elevated irregular temperature was again present, with persisting signs of paranasal sinus suppuration. The urine continued to show a large amount of albumin with gross or microscopic blood. A few weeks after returning home the patient died.

Case 25. Daniel S. In July, 1924, when the patient was 9 years of age, edema and albuminuria were noted for the first time. Edema later disappeared and recurred at intervals, but albuminuria persisted. From February, 1925, until the time of this writing, the patient was followed closely as he developed severe chronic nephritis. A chronic pansinusitis, with occasional acute exacerbations persisted despite treatment for several years.

Case 26. Marie $\mathrm{H}$. This patient was followed either in the hospital or in the out-patient department from January 2, 1924 to the time of her death, October 4, 1926. In September, 1923, following an upper respiratory infection, associated with a very profuse yellow nasal discharge, there occurred almost complete suppression of the urine, drowsiness and edema of the face and ankles. For two months, the edema continued, fluctuating to some extent, despite bed rest and steam baths. On January 2, 1924 a few days after an acute increase of edema, she was admitted to the hospital. The edema noted was generalized. The urine contained a large amount of albumin, a few casts and leucocytes and occasionally a few red blood cells. There was no non-protein nitrogen retention in the blood. Her blood pressure, however, was 180/130. Albuminuric retinitis was present. The phenolsulphonephthalein output on three occasions was 45, 25 and 30 per cent. The specific gravity of the urine collected during a Mosenthal test varied from 1.008 to 1.020. Chronic tonsillitis, enlarged adenoids, rhinological and $x$-ray evidence of paranasal sinusitis were found. Despite removal of the tonsils and adenoids and radical operative treatment of the paranasal sinusitis, renal insufficiency gradually progressed. Death occurred on October 4, 1926 from cardiac failure. 
Case 27. Emma P. Age, 11 years. Diagnosis: Chronic nephritis with hypertension and uremic convulsions.

Case 28. Robert D. Age, 5 years. Diagnosis: severe renal insufficiency, possibly developmental (polycystic kidneys?).

Case 29. Joe B. Age, 6 years. Diagnosis: Chronic nephritis with hypertension and uremia.

Case 30. Leo D. Age, 9 years. This patient was healthy during infancy and early childhood, except for a few mild attacks of sore throat. He had had no contagious diseases. At the age of five years he had an attack of nausea and vomiting, which lasted for several weeks. A physician at that time diagnosed anemia and kidney trouble. Two years later he developed pain in his right side, which recurred frequently. During the year of 1927 he had several attacks of epistaxis. He was kept from school because of weakness, but for the most part remained up and about. Ten days before admission to the hospital on September 9,1927 he developed persistent vomiting accompanied by pain in his right side. For a short time gross blood was noted in the urine.

When examined in the hospital, he was found under-developed, poorly nourished and moderately dehydrated. He was at times quite irritable but usually was very drowsy. Slight hyperpnea was present. No infection was found in his nose or throat. His heart and lungs were normal. There was fullness and tenderness in the right kidney region. The urine contained a large amount of albumin, many pus cells, a few red blood cells and granular casts. Chemical study of his blood showed a marked deviation from the normal (see table 2). The blood pressure was $110 / 65$.

He lived fifteen days after admission, continuing to vomit practically everything taken by mouth, and becoming progressively weaker. During the 24 hours before death, he was in coma and had frequent convulsions.

At autopsy, in place of the left kidney, was a small amount of tissue, weighing a few grams, which on section proved to be kidney tissue. The right kidney was small, but polycystic with superimposed pyonephrosis. There was very little good kidney tissue remaining (approximately one-tenth the normal amount).

Case 31. June T. Age, 2 years. This patient had seemed well until 17 months of age, when she developed diphtheria. Following this she developed very marked polyuria and polydypsia. She gradually lost weight and appetite. Three weeks before admission she vomited considerably and apparently had some fever. She was frequently very drowsy. When examined at the hospital on December 12, 1927 she was found underdeveloped and much undernourished. Moderate but definite dehydration and hyperpnea was present. In other respects, physical . findings were normal. The urine, despite the dehydration, was very dilute, with 
$\mathrm{pH}$ of approximately 6.5 and with but 2 to $3 \mathrm{mgm}$. ammonia nitrogen per $100 \mathrm{cc}$. A considerable amount of albumin was present, and the sediment was composed chiefly of granular casts and white blood cells. There were occasional hyalin casts. The Mosenthal test showed fixation of the specific gravity between 1.001 and 1.004. The concentration of non-protein nitrogen was never more than 240 mgm. per cent. The concentration of chloride varied between $53 \mathrm{mgm}$. and 99.5 mgm. per cent $\mathrm{NaCl}$. The phenolsulphonephthalein output was 19 per cent in 2 hours.

Polydypsia remained marked and all urine was as described above. Intramuscular injection of pituitrin had no effect on the concentration of the urine. With a high caloric diet, largely milk, she gained weight rapidly. Because of the diminished $\mathrm{CO}_{2}$ content of the blood (see table 2), large amounts of orange juice, as an additional source of alkali, were given.

Case 32. Woodrow W. Age, 9 years. Diagnosis: Acute hemorrhagic nephritis when first seen which progressed into fatal chronic nephritis.

Case 33. Davis B. Age, 13 years. Findings were those of chronic nephritis with hypertension (blood pressure 210/160) and myocardial damage.

Case 34. Margaret Q. Age, 12 years. Diagnosis: chronic nephritis with edema and hypertension.

Cases 35 and 36 . These cases were male adults showing evidence of renal insufficiency associated with prostatic hypertrophy. They are included because of the rather complete blood data which we were able to obtain from them and because they seemed in many respects like the children studied with marked renal insufficiency.

\section{Cases of subacute and chronic glomerular nephritis}

When acute glomerular nephritis is not completely recovered from, fibrous tissue replacement of kidney substance involving chiefly the glomeruli results. Autopsy of cases of severe chronic nephritis with evidence of marked renal insufficiency frequently shows very little normal secreting tissue remaining. It is, therefore, natural to assume that the chemical blood picture of severe chronic nephritis is the result of inadequate urinary secretion. It did not seem correct to us, however, to look upon non-protein nitrogen increase in the blood as conclusive evidence of renal insufficiency in cases of acute glomerular nephritis, and the data from the following cases of subacute and chronic nephritis make us feel that non-protein nitrogen increase in 


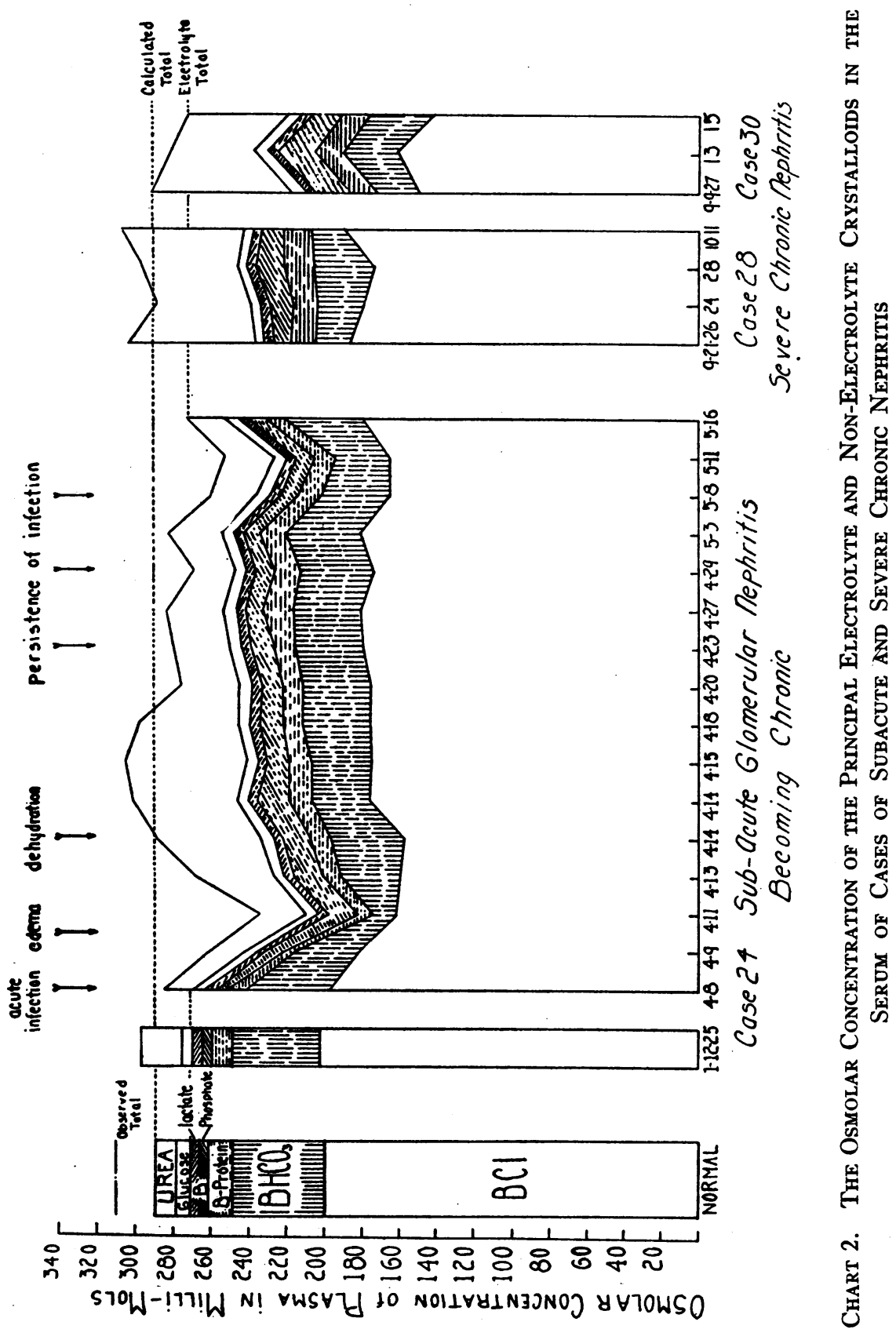


the blood has the same significance that it has in acute nephritis. In subacute or chronic nephritis, exacerbation of infection which provokes vomiting, diarrhea, or edema may have the same marked effect in lowering the electrolyte content of the blood and raising the non-protein nitrogen that it has in acute nephritis. In the absence of acute infection, however, the same result may occur more gradually, because of faulty urinary secretion which permits electrolyte to be lost from the blood.

\section{Results of acute infection in sub-acute or chronic nephritis}

When a severe exacerbation of infection in the form of paranasal sinusitis and septicemia by a hemolytic streptococcus occurred in case 24, on April 8, 1925, there followed a sudden appreciable reducrion in concentration of serum chloride and bicarbonate (table 2, chart 2). If our single determination was correct, protein also suffered a transient but marked fall in concentration. ${ }^{1}$ At the same time, edema appeared. Even in the absence of lactic acid and total base determinations, it seems certain that, as calculated, the osmotic pressure due to electrolyte suddenly diminished to a very marked degree; as calculated from $264 \mathrm{mM}$. osmolar to $204 \mathrm{mM}$., a diminution of 22.8 per cent. Coincident with the fall in $\mathrm{BCl}$ and $\mathrm{BHCO}_{3}$, nonprotein nitrogen and phosphate increased in the blood, so that the total calculated osmolar concentration dropped somewhat less (17 per cent) than that of the electrolyte alone. On April 14, although the osmolar concentration of electrolyte was still much reduced, the total theoretical osmolar concentration was slightly higher than normal, due largely to increase in non-protein nitrogen. Edema had disappeared by this time. During the next few days; when the total osmolar concentration exceeded slightly the normal, ${ }^{2}$ the reverse of edema, desiccation, was noted. Gradually, however, electrolyte

${ }^{1}$ The low plasma protein value on April 9th, however, is questionable, since determinations a short time previously and subsequently agreed well with each other and were both considerably higher than the value in question.'

${ }^{2}$ As in case 21 , the theoretical osmotic pressure was probably greater than the actual value when the non-protein nitrogen reached a very high level. In all probability, the non-protein nitrogen did not overcompensate osmotically for loss of electrolyte as much as our calculation would indicate. 
increased and non-protein nitrogen decreased, and again a normal total osmolar concentration was maintained, but with noticeably less electrolyte and more non-protein nitrogen present in the blood than before the onset of the infection. Again a normal water balance between blood and tissues was maintained, so that neither edema nor dehydration was present.

In case 26 (table 2) similar changes are encountered in an individual showing evidence of subacute nephritis. Exacerbation of paranasal sinus infection on several occasions, but particularly on October 15, 1925 was followed by loss of electrolyte from the blood and by the appearance of transient edema, which disappeared as a normal total osmolar concentration was established by increase in non-protein nitrogen. In case 25 the effect of marked vomiting on the composition of the blood is shown on February 20, 1928, and February 23, 1928.

The composition of the blood in severe chronic nephritis and the rôle played by altered urinary secretion

After a sufficient length of time, the chemical composition of the blood of our cases of severe chronic nephritis even in the absence of acute infection, showed a reduction of total base, and of such anions as $\mathrm{HCO}_{3}{ }^{\prime}$ and $\mathrm{Cl}^{\prime}$, with increase of $\mathrm{HPO}_{4}{ }^{\prime \prime}$ and of non-protein nitrogen. In this respect our findings in children are in agreement with those found in adults by Bulger and Peters and their coworkers (8) and Straub (9). Bulger and Peters, however, frequently found much more base than could be accounted for by the sum of the principal acids determined $\left(\mathrm{Cl}^{\prime}+\mathrm{HCO}_{3}{ }^{\prime}+\right.$ protein' $\left.{ }^{\prime}+\mathrm{HPO}_{4}{ }^{\prime \prime}\right)$. This led them to conclude that some other type of acid was present which replaced bicarbonate and chloride from combination with base. Although admitting the possibility of sulfate increase, as shown frequently to occur in severe nephritis by Dennis (10), they felt that some organic acid was chiefly responsible. As can be noted in our tables, we very rarely found a marked increase in total base over the sum of the same individual acids which Bulger and Peters determined. In addition we frequently determined lactic acid, finding it not increased except when convulsions or circulatory failure with cyanosis occurred, and also ruled out the presence of diacetic acid in appreciable amounts. In our case 25, on February 20, 1928 sulfate was determined and 
found to be the equivalent of $10 \mathrm{mM}$. univalent base. We are inclined to believe, therefore, that in other instances in which undetermined acid seemed unusually large, as for instance cases $26,28,30$, and 36 , sulfuric acid was in all probability chiefly responsible.

In different types of nephritis, Straub studied the blood from an acid-base viewpoint by determining individually the base ions, Nà, $\mathrm{K}^{\prime}$, and $\mathrm{Cä}$ and the principle acid ions, $\mathrm{Cl}^{\prime}$ and $\mathrm{HCO}_{3}{ }^{\prime} \mathrm{He}$ did not determine phosphoric, sulfuric, or lactic acid, and did not attempt to calculate the base-binding capacity of the protein. He did, however, besides determining the non-protein nitrogen, determine the actual freezing point and the electrical conductivity of the serum. He frequently found, as did later Bulger and Peters and ourselves, considerable variations in $\mathrm{Cl}^{\prime}$ and $\mathrm{HCO}_{3}{ }^{\prime}$ ions, usually but not always in opposite directions. Total base $(\mathrm{Na}+\mathrm{K}+\mathrm{Ca})$ he found sometimes normal, but occasionally below or above normal. He also occasionally found an unusual excess of "total" base over the sum of $\mathrm{Cl}^{\prime}$ and $\mathrm{HCO}_{3}{ }^{\prime}$ ions. This difference in some cases he did not believe due to phosphoric, sulfuric or proteic acid, but to some unknown pathological acid. This type of substance, together with a theoretical non-electrolyte (not non-protein nitrogen) constituted what he termed "molrest;" that is, the difference between the calculated and the observed osmotic pressure in millimoles.

Recalculating his most complete data as we have calculated ours, we find the difference between "total" acid and total base no greater than indicated by our data, and very little undetermined osmotically active substances except in one case (no. 7 on July 23, 1923). In this instance, the total base found was $61 \mathrm{mM}$. greater than the sum of the principal normal acids $\left(\mathrm{Cl}^{\prime}+\mathrm{HCO}_{3}{ }^{\prime}+\right.$ protein'). This is the only instance in which there was such a marked discrepancy between base and acid. In this case we should have expected very high values for phosphate and sulfate, together perhaps binding 25 to $30 \mathrm{mM}$. univalent base. In addition, if marked circulatory failure had existed (as it very well might so shortly before death) lactic acid might have accounted for 10 to $15 \mathrm{mM}$. more base. By accumulation of these three acids, therefore, 35 to $45 \mathrm{mM}$. of the $61 \mathrm{might}$ have been accounted for. In such an event, no very great amount of unusual acid needs to have been present. If we calculate the total 
osmolar concentration from the determined acids, plus the observed non-protein nitrogen, we can account for but 77 per cent of the observed osmotic pressure. If, on the other hand, we allow for the osmotic pressure of the salts indicated by the excess of total base overthe acids $\mathrm{Cl}+\mathrm{HCO}_{3}+$ protein, assuming even that they were entirely undissociated, and for a normal glucose content, we have no difficulty in accounting for 90 per cent of the observed osmotic pressure. In this case, therefore, there also seems to be little evidence for assuming any significant amount of "mol-rest."

The reduction of $\mathrm{BHCO}_{3}$ or acidosis in our cases of severe chronic nephritis can only in part be explained by increase in acid such as phosphoric, sulfuric and lactic. Total base, as well as "total" acid was decreased and to about the same degree. It seems certain, therefore, that fixed base was most from the body.

Explanation of the means by which $\mathrm{BHCO}_{3}$ was lost from the body is to be found in the faulty secretion of the urine. The rôle which the normal kidney plays in assisting in the maintenance of a normal concentration of fixed base in the body fluids has been most clearly shown by Gamble, Ross and Tisdall (1) in their study of the metabolsm of fixed base during fasting. Fixed base economy is practiced by the kidney in time of need in two ways: (1) by means of maintaining the acidity of the urine at its maximum ( $\mathrm{pH} 5$ ) thus permitting the excretion of no $\mathrm{BHCO}_{3}$ from the blood, allowing organic acid to be in part unneutralized, and effecting about a 40 per cent saving of base bound to phosphoric acid; and (2) making and substituting ammonia for the fixed base of the plasma salts of which the anions need to be fully neutralized when excreted. How far the damaged kidney in severe nephritis fails to exert such base economy can be noted in several of our cases. In case 24 , for instance, it can be seen that previous to the severe infection beginning on April 28 there was a slight reduction of $\mathrm{BHCO}_{3}$ in the blood. The urine at this time, however, approached its maximum acidity ( $\mathrm{pH} \mathrm{6}^{-}$) and showed a strong qualitative reaction for ammonia. During the period of infection and afterwards, however, despite a sometimes marked reduction of serum $\mathrm{BHCO}_{3}$ the urine contained little or no ammonia. The kidney was still able to secrete urine of at least approximately normal maximum acidity. In cases $25,26,29,31$, and 32 and 35 a similar inability to substitute 
ammonia for fixed base was noted, and cases 31,32 and 36 also showed inability to practice base economy by excreting urine of maximum acidity.

Such inability of the damaged kidney to practice base economy has been demonstrated experimentally by Begun and Munzer (11), Beckman (12) and Linder (13) in a more direct manner. After hydrochloric acid feeding in normal subjects and nephritics, a lesser excretion of ammonia and a greater excretion of fixed base was demonstrated in the urine of nephritics. In our case 28 there evidently had been severe renal insufficiency and "acidosis" for a considerable time and loss of the fixed base of the body seemed to have included also the calcium of the bones, producing a type of "renal" rickets.

The reason for the diminution of serum $\mathrm{BCl}$ in the absence of vomiting and edema seems also to lie in the faulty secretion of urine. Although our data on this point is not quantitative, it suggests at least that when there is a tendency towards secretion of large quantities of dilute urine, chloride may be present in the urine in considerable amount despite an abnormally low concentration in the serum. This is analagous to the chloride loss accompanying the polyuria of some cases of diabetes insipidus and diabetes mellitus. It is not inconceivable that such chloride loss in the urine, though relatively little, might eventually deplete the body if the chloride intake were restricted. Because of the inability of the kidney to practice base economy, such loss of chloride would also be attended by loss of fixed base.

It is of particular interest, however, that the osmotic pressure of the blood neither theoretically nor experimentally was found to be reduced, despite this reduction in $\mathrm{BHCO}_{3}$ and $\mathrm{BCl}$. This was due to the fact that non-protein nitrogen was increased to a point sufficient to make up osmotically for the loss of electrolyte from the blood. This apparent compensation of a non-electrolyte for electrolyte in the maintenance of normal osmotic pressure in cases of chronic nephritis has also been noted in cases of marked vomiting due to pyloric or intestinal obstruction (2), in which electrolytes have been lost from the body and non-protein nitrogen retained. That such a mechanism may exist normally in some of the lower forms of life is suggested by the observation of MacCallum (14) that in the dogfish about one-third 
the normal osmotic pressure of the blood is maintained by urea and ammonium salts. This relationship was very similar to that found in cases 22, 23 and 24 . It also suggests, to us at least, that the blood changes in chronic nephritis with renal insufficiency do not result primarily from inability of the kidneys to secrete urea, but are caused by their inability to practice base economy by regulating the acidity of the urine and substituting ammonia for the fixed base of the plasma salts when the acid radicals are excreted. This loss of fixed base from the body, leading to a lowering of its $\mathrm{BHCO}_{3}$ concentration, together with the frequent failure to retain $\mathrm{BCl}$, despite its reduction in the blood, is osmotically compensated for by retention of non-protein nitrogen (chiefly urea).

This view, we realize, will not be easily accepted. Gram (15), for instance, has suggested just the opposite, i.e., excretion of electrolyte in response to retention of non-protein nitrogen. In addition, it has quite generally been thought that the accumulation of non-protein nitrogen in the blood of cases of renal insufficiency resulted from inability of the kidneys to excrete urea. Experimental basis for such a view, however, seems to be lacking and one is forced to wonder why such a freely diffusible substance as urea should meet with such great difficulty in excretion', when other larger and more complex molecules, such as some of the electrolytes and albumin meet no such difficulty. The uncertainty of our knowledge concerning the normal secretion of urine, however, makes it folly for us, at the present time, to attempt to explain how urea is retained in the body. Some direct experiments ${ }^{3}$ on the effect of administration of various electrolytes and nonelectrolytes on the composition of the blood and urine will be conducted and we hope will throw some light on this question.

\section{SUMMARY AND CONCLUSIONS}

The composition of the blood serum in glomerular nephritis was studied as follows:

${ }^{3}$ The response of case 36 to administration of sodium bicarbonate and sodium chloride and discontinuation of large amounts of water by mouth (and therefore polyuria) was most encouraging. Electrolyte increased in the blood, while urea decreased. The actual osmotic pressure remained constant. 
(1) The concentrations of the principal anions, $\mathrm{Cl}^{\prime}, \mathrm{HCO}_{3}{ }^{\prime}$, protein, $\mathrm{HPO}_{4}{ }^{\prime \prime}$ and lactate, and the actual $\mathrm{pH}$ were determined.

(2) Total base was determined directly, and from its value and the sum of the five principal acids determined the concentration of undetermined acid was obtained.

(3) The principal non-electrolyte substances, non-protein nitrogen (urea) and glucose were determined.

(4) The freezing point of the serum was determined and from it the total osmolar concentration of the serum was calculated.

(5) A method of calculating the theoretical total osmolar concentration from the concentration of the principal individual solutes, electrolyte and non-electrolyte, was developed.

In addition, the composition of the urine was studied to some extent, and after correlation of the observed changes in the chemical composition of the blood serum and urine with the clinical symptoms and findings, it was concluded that:

(1) In acute hemorrhagic nephritis, marked changes in the chemical composition of the blood occur only when such symptoms as severe vomiting or diarrhea, edema or dehydration, or convulsions occur.

(2) When these changes include a reduction of the total electrolyte content of the blood serum, urea is found increased to such an extent that no reduction in osmotic pressure occurs.

(3) Such urea increase should be considered compensatory and not due to an inability of the kidney to excrete urea.'

(4) In subacute and chronic glomerular. nephritis, acute infection causing similar symptoms results in similar changes.

(5) In the absence of such symptoms, however, much the same changes occur, but more gradually, as the result of faulty urinary secretion which includes: (a) failure to practice fixed base economy by substituting ammonia for the fixed base of the plasma salts when the acid radicals are excreted, and $(b)$ a failure to secrete urine of normal maximum acidity, i.e., free from $\mathrm{BHCO}_{3}$ and $(c)$ a failure to retain $\mathrm{BCl}$ in the plasma, and (d) a failure to excrete sufficiently such acids as phosphoric and sulfuric.

(6) The loss of plasma electrolyte due to such faulty urinary secretion is compensated for, osmotically, by retention of urea. 


\section{BIBLIOGRAPHY}

1. Gamble, J. L., Ross, G. S., and Tisdall, F. F., J. Biol. Chem., 1923, lvii, 633. The Metabolism of Fixed Base During Fasting.

2. Hartmann, A. F., and Smyth, F. S., Am. J. Dis. Child., 1926, xxxii, 1. Chemical Changes in the Body Occurring as the Result of Vomiting.

3. Hartmann, A. F., Am. J. Dis. Child., 1928, xxxv, 557. The Effects of Diarrhea, Vomiting, Dehydration and Oliguria on the Acid-Base Balance of the Plasma of Infants with Mastoiditis.

4. Landolt, Börnstein, Physikalisch-Chemische Tabullen. Springer, Berlin, 1923.

5. Hastings, A. B., Salvesen, H. A., Sendroy, J., and Van Slyke, D. D., J. Gen. Physiol., 1927, viii, 701. Studies of Gas and Electrolyte Equilibria in the Blood. IX. The Distribution of Electrolytes Between Transudates and Serum.

6. Van Slyke, D. D., Wu, H., and McLean, F. C., J. Biol. Chem., 1923, lvi, 804. Studies of Gas and Electrolyte Equilibria in the Blood. V. Factors Controlling the Electrolyte and Water Distribution in the Blood.

7. Blackfan, K. D., and Hamilton, B. Johns Hopkins Hosp. Bull., 1927, xli, 322. A Study of the Inorganic Constituents of the Serum in Children with Acute Nephritis.

8. Bulger, H. A., Peters, J. P., Eisenman, A. J., and Lee, C., J. Clin. Invest., 1926, ii, 213. Total Acid-Base Equilibrium of Plasma in Health and Disease. VII. Factors Causing Acidosis in Chronic Nephritis.

9. Straub, H., Ergebnisse der innern Medizin und Kinderheilkunde, 1924, xxv, 137, Störüngen der physikalish-chemischen Atnungsregulation.

10. Denis, W., J. Biol. Chem., 1921, xlix, 311. Sulfates in Blood.

11 and 12. Quoted by Straub (9).

13. Linder, G. C., Quart. J. Med., 1927, xx, 285. The Effect of Mineral Acid on Acid-Base Regulation in Health and in Nephritis.

14. McCallum, A. B., Proc. Royal Soc. London, Series B, 1910, lxxxii, 617. The Inorganic Composition of the Blood in Vertebrates and Invertebrates and Its Origin.

15. Gram, H. C., J. Biol. Chem., 1923, lvi, 593. Observations on the Regulation of Osmotic Pressure (Conductivity, Chlorides, Freezing Point and Proteins of Serum). 